\title{
KNOWLEDGE INFRASTRUCTURE IN REGIONS AS THE QUALITY OF BUSINESS ENVIRONMENT FACTOR
}

\author{
Vladimír Žítek, Viktorie Klímová, Milan Viturka
}

\section{Key words}

Universities and colleges, education, research and development, knowledge infrastructure, science and technology parks, business incubators

\section{Klíčová slova}

Univerzity a vysoké školy, vzdělávání, výzkum a vývoj, znalostní infrastruktura, vědeckotechnické parky, podnikatelské inkubátory

\begin{abstract}
The assessment of knowledge infrastructure, implemented on the level of administrative districts of authorized municipalities - 206 units in total, is aimed at the institutional support for knowledge base development, the fundamental component of which is the infrastructure for education. The main attention is paid to the complexity of appropriate supply. The main objective of the article is dividing of districts into five qualitative groups and their synthesis by regions. The biggest weight is assigned to the location of public universities in regions, lower weight to private universities, colleges and secondary schools. The obtained data about the educational infrastructure has been complemented by an analysis of location of science and research institutes, science and technology parks and business incubators. The most significant centres found in the best classification group are Prague and Brno. The second group contains all the remaining regional capitals except Karlovy Vary, together with Opava - a traditional university centre. The strongest centre within this group is Ostrava, the weakest is Jihlava. Based on this dividing, possibilities to influence the characteristics of knowledge infrastructure factors in the future were suggested.
\end{abstract}

\begin{abstract}
Abstrakt
Hodnocení znalostní infrastruktury, prováděné na úrovni správních obvodů obcí s rozšířenou působností, tzn. 205 jednotek, je orientováno na institucionální zabezpečení rozvoje znalostní báze, jehož základní komponentu tvoří infrastruktura pro vzdělávání. Hlavní důraz byl položen na komplexnost odpovídající nabídky. Hlavním cílem příspěvku je rozdělit správní obvody obcí s rozšířenou působností do pěti kvalitativních skupin a provést jejich syntézu dle krajů. Největší váha byla přiznána přítomnosti veřejných vysokých škol v regionu, menší pak následně soukromým VŠ, vyšším odborným a středním školám. Zjišstěné informace o infrastruktuře vzdělávání byly doplněny analýzou rozmístění vědeckých a výzkumných ústavů a dále vědecko-technických parků a podnikatelských inkubátorů. Jako nejvýznamnější centra zařazená do nejlepší klasifikační skupiny byly identifikovány Praha spolu s Brnem. Do následující 2 . skupiny byla zařazena všechna zbývající krajská města s výjimkou Karlových Varů, doplněná tradičním vysokoškolským centrem Opavou. Nejsilnějším centrem v rámci této skupiny je Ostrava a naopak nejslabším centrem Jihlava. Na základě tohoto rozdělení jsou navrženy možnosti, jak lze ovlivnit faktory znalostní infrastruktury v budoucnosti.
\end{abstract}

\section{Introduction}

The paper was elaborated within the project of the Czech Science Foundation no. GA402/08/0071: "Regional Assessment of Business Environment Quality from the Perspective of the Innovation Development and Transfer Potential". The project focuses on 
individual factors of the quality of business environment and partial analyses of these factors form the basis for a complex assessment (Viturka et al, 2010). One of the factors is the factor of knowledge infrastructure, which is for the purposes of the project combined with the factor of business infrastructure. With respect to the article extent, only the knowledge infrastructure factor is presented.

The assessment of knowledge infrastructure is oriented at the institutional support for the development of the knowledge base, the main component of which is the infrastructure for education (the source of information was mainly the statistics of the Institute for Information on Education (Yearbooks) and the data of the Czech Statistical Office - the database of the Town and Municipal Statistics). The main emphasis was put on the complexity of an appropriate supply.

\section{Aim of the Study}

The aim of the article is to carry out assessment of knowledge infrastructure of Czech districts (administrative districts of municipalities). This assessment is one of several parts of business environment evaluation that have been conducted in the framework of the above-mentioned project. The research study has two main results: firstly, dividing of districts into five qualitative groups and their synthesis by regions, and secondly, suggestions of possibilities to influence the characteristics of knowledge infrastructure factors in the future.

\section{Materials and methods}

The evaluation of business environment quality is based on an approach the core of which is the identification of investment or development preferences of entrepreneurs. These preferences can be expressed in a concentrated way which is based on a pre-defined set of business environment quality factors. The multifactor evaluation of business environment quality (BEQ) respects the logics of modern concepts of location analyses, which put the main stress on the consideration of the corresponding entrepreneurs' demands.

The own methodology of BEQ assessment is based on territorially bound and consists of 16 factors, which are divided into six groups - business, labour-related, infrastructure-related, local, price-related and environmental. Generally speaking BEQ represents an aggregate result of a long-term regional accumulation of various influences generated by activities of entrepreneurial and non-entrepreneurial entities.

For the evaluation of BEQ to be possible it is necessary to have relevant estimates of appropriate degrees of significance of the selected factors. These can be established with the demanded degree of objectivity using qualified international surveys of corresponding opinions of potential investors and subsequent statistical and other analyses. For this purpose, especially the data found out by the Netherland Economic Institute in cooperation with the well-known advisory and auditing company Ernst and Young (1993) were used, together with the results of other international surveys carried out by recognized European institutions (e.g. IFO Munich, 1989).

It is necessary to emphasize that the establishment of the degrees of factor significance is largely influenced by the adaptation to the conditions of the 'knowledge economy', which considers innovations as the main drive of significant development. The transition to the knowledge economy is connected especially with the weakening of the overall significance of infrastructure-related factors and also of a comparable significance of some partial factors (e.g. the factor of public administration assistance). On the other hand, there is an increase in 
the overall significance of labour-related factors (the factor of workforce quality), environmental factors and some partial factors (especially the business and knowledge base factor; compare to Viturka et al, 2003).

The territorial units used for the regional evaluation of BEQ were administrative districts of municipalities with extended competence. The total number of these districts in the Czech Republic is 205+1 (including the territory of the capital - Prague). These units are not included in the European system of NUTS; districts represent a level between LAU 1 and LAU 2. From a regionalist perspective, these units represent a microregional level of evaluation.

With respect to the period in which the research project was being solved it was necessary to set 2006 as the time basis. Therefore, values of monitored indicators are related to this year. In our opinion it does not reduce the level of objectives fulfilment nowadays. It can be easily proved that the values of most indicators (number of universities, colleges, research institutes or secondary schools; compare to Ministerstvo školství, mládeže a tělovýchovy) have not changed or their change has not influenced our results.

The evaluation of the selected BEQ factors in the individual regions was then carried out in the agreement with classification which had been developed and thoroughly verified in practice before. The classification divides the regions units into five groups: 1st group values well above average; 2nd group - values slightly above average; 3rd group - average values; 4th group - values slightly below average; and 5th group - values well below average. If the values were placed in a position similar to usual statistical distribution, the limits of individual classification groups were set on the basis of the standard order from the 1st to the 5th group ( $\mathrm{x}=$ arithmetic mean, $\mathrm{Sx}=$ standard deviation): $\mathrm{x}$ and $\mathrm{Sx}, \mathrm{x}+0.33 \mathrm{Sx}, \mathrm{x}-0.33 \mathrm{Sx}$, $\mathrm{x}-\mathrm{Sx}$. In the other cases, the limits of the classification groups were set by means of specific procedures adapted, besides the statistical distribution of the values of the factors, to their factual character (Viturka, Žítek, Klímová, Tonev, 2010).

In this article the attention is paid only to one part of the business and knowledge base factor (the most significant factor of BEQ evaluation), i.e. the knowledge base (Education infrastructure and Research and Development Infrastructure). This factor plays an important role within the regional approach to assessment of business environment quality and it is not usually involved in the national approaches (e.g. Kočišová, Tartal’ová, 2010).

\section{Education Infrastructure}

At the first stage, the attention focused on the assessment of a regional distribution of universities and colleges (UC), with the emphasis on public universities and colleges (PUC), which are of the essential significance for tertiary education. In total, the evaluation included 25 PUC, which were divided into two groups: A - a group of all PUC except art schools. These were classified as group B, together with both Czech state-owned universities (SOU). Therefore, group A consists of 20 PUC and group B consists of 5 PUC +2 SOU. Moreover, the placement of isolated faculties of PUC - 7 faculties in all - was taken into account. Private universities and colleges (PrUC) were only assigned with an auxiliary significance (PrUC do not get any financial subsidies from the state and the basis of their financing is tuition fees) as the proportion of the students who attend them is relatively low - in the explored period of school year 2006/07 it was $9.8 \%$. In total, 42 PrUC were included. These were again divided into two groups, group A (34 schools) and group B (8 schools). The 
division was based on the number of students (with respect to the trend for the following school year) with group B consisting of the "small" PrUC up to 100 students. Most PrUC are located in Prague (24) and Brno (5). Their study fields mostly concentrate on social sciences, especially economy and public administration. Based on the conducted analyses, MBA providing schools were not included in the evaluation.

The presence of PUC was established as the main criterion for the classification of districts into one of the groups above average, generally consisting of the knowledge infrastructure centres of national (supraregional) significance. Centres with only PrUC or an isolated faculty of a PUC were classified in the third group, which is characterized by a regional significance of their knowledge infrastructure. This group further contains centres with a high concentration of secondary schools (SndS) together with higher vocational schools (HVS, the system of organizing studies is similar to universities and colleges; however, the achieved education is not considered equal with these and the graduates are usually the students who did not pass entrance examinations to UC), where the lower limit was set as the minimum of 10 schools, or 9 schools including 1 HVS. The classification of these centres (or appropriate microregions) into a group considerably reflects their hierarchic and functional position within the system of municipalities of the Czech Republic. The infrastructure of SndS consists of 1696 schools, out of which 350 are comprehensive schools, 798 are secondary vocational schools, and 548 are secondary vocational practical schools (combined with apprenticeships); the infrastructure of HVS consists of 176 schools (mean values of 1 microregion are 8.2 and 0.9; the corresponding shares of Prague together with Brno are 16 and $27 \%$; Ústav pro informace ve vzdělávání). The analysis is based on the end of school year 2005/06 - in the following years there were obvious integration tendencies of SndS founders and their number decreased (by about 200 schools). The other microregions were classified into one of the groups below average - the fourth group has the limit of at least 4 schools, including comprehensive schools and secondary vocational schools.

\section{Research and Development Infrastructure}

The information we gained on the education infrastructure was combined with the information gained from the analysis of the location of science and research institutes and also science and technology parks (STP) and business incubators (BI). The segment of science and research institutes contains public research institutes (PRI) - these are organizations with their own legal person dealing with research and development, financed mostly from public means. They are usually restructured former departments of the Academy of Sciences of the Czech Republic (the Academy is now their founder), or research institutes founded by the state (or its organizational bodies) or territorial self-governing units (Ministerstvo školství, mládeže a tělovýchovy). These research institutes were divided into two basic groups - those founded by the Academy of Science and the others (departmental). The Academy of Sciences of the Czech Republic is currently a founder of 54 institutes in total and these were divided into group A - containing 35 institutes oriented at natural sciences, technology, medicine and information - and group B - containing the remaining 19 institutes focusing on academic sciences (arts). The source of data was the Registry of Public Research Institutes. Thirty-nine, i.e. $72 \%$ of these institutes, are located in Prague; another more significant centre is Brno with its 7 institutes. Six institutes are located outside regional capitals (a concentration of the basic research in the largest centres can be considered logical; however, the proportion of the capital is completely extreme when compared with other countries of the EU). Similarly, departmental (sectoral) research institutes were divided in the following way: group A contains 12 institutes and group B 8 institutes. Prague has a half share and 6 institutes are located outside regional capitals. The mentioned information (see above the commentary on 
the concentration of institutes within the largest centres) was used for disputable cases if necessary.

The gradually developing structure of STP and BI serves to support the increase in the quality of used technologies and products, in other words the innovation potential, especially by means of providing related services (elaboration of business plans, feasibility studies and development projects, or common tax, accounting and legal services) and their connection with universities and colleges or other public science and research institutes (commercialization of the results of science and research) (Konečný, Skokan, Zamarský, 2001).

The collected data for about 18 STP and 13 BI (operating at the end of 2006) was used for the purpose of the final evaluation of the regional values of the business and knowledge base factor. Science and technology parks are associated in the Association of Science and Technology Parks on the basis of accreditation. They are often located in the vicinity of cities (especially in central Bohemia near Prague) or in the suburbs of larger towns. Business incubators are quite often established in smaller municipalities as well; however, BI concentrating on innovations are mainly found in locations with science and research infrastructure. STP and BI started to develop more rapidly after the Czech Republic entered the EU as the infrastructure is supported plentifully from structural funds. The position and the significance of individual STP and BI differ according to a particular region; however, their location is more territorially balanced in comparison with science and research institutes - less than a half of STP and BI are located in regional centres.

\section{Results}

The results of the regional evaluation of the knowledge infrastructure subfactor naturally confirm its growing transition from lower to higher levels of education. This fact determines the commuting of students to the corresponding centres (commuting to the sources of tertiary education is often used to identify natural mesoregional centres - see e.g. Hampl, 2005).

The most significant centres found in the best classification group are Prague and Brno, in both of which 5 PUC are located. The fact that Brno is classified within the same category as Prague, in spite of the considerably lower number of PrUC and science and research institutes, is justified by their similar position from the point of view of the "production" of graduates of technical, natural sciences (including informatics) and medical (including pharmacy) fields of study with the highest potential impact on the development of innovations (Tonev, 2007).

The second group contains all the remaining regional capitals except Karlovy Vary, together with Opava - a traditional university centre. The strongest centre within this group is Ostrava, the weakest is Jihlava - this town was classified within the second group due to the fact that besides the recently established PUC (in the process of quantitative growth, there are over 1,500 students, dominating fields are those related to tourism, finance and management, but also computer systems and health care), there is a relatively high number of secondary schools and HVS (the $6^{\text {th }}$ or the $3^{\text {rd }}$ position within the identified group of regional capitals).

The third group with the prevailing regional significance of the knowledge base includes 45 districts, three quarters of which are larger than 50 thousand inhabitants (in the cases of Mělník district and Třeboň district, their classification within this group was determined basing on the location of some of the other institutes of the knowledge infrastructure). Four of these centres contain an isolated faculty of PUC, nine of them contain a PrUC. 
The highest number (87) districts are within the $4^{\text {th }}$ group (the final classification of Trhové Sviny district within this group was determined basing on the location of some of other institutes of the knowledge infrastructure). The districts in this group are characterized by the predominant intraregional significance of their knowledge base (the regional significance is only obvious if a narrowly specialized HVS is located there) and an absent option of tertiary education. Nearly $90 \%$ of these have fewer than 50 thousand inhabitants (about a third of them have fewer than 25 thousand inhabitants).

The remaining 61 districts are contained within the $5^{\text {th }}$ group with only microregional significance of their knowledge base. These districts can only offer a narrow range of secondary education institutions, HVS are absent, in extreme cases they do not even have any relevant offer ( 5 districts). The population of approximately $90 \%$ of these is fewer than 25 thousand inhabitants.

Graph 1 Representation of established groups

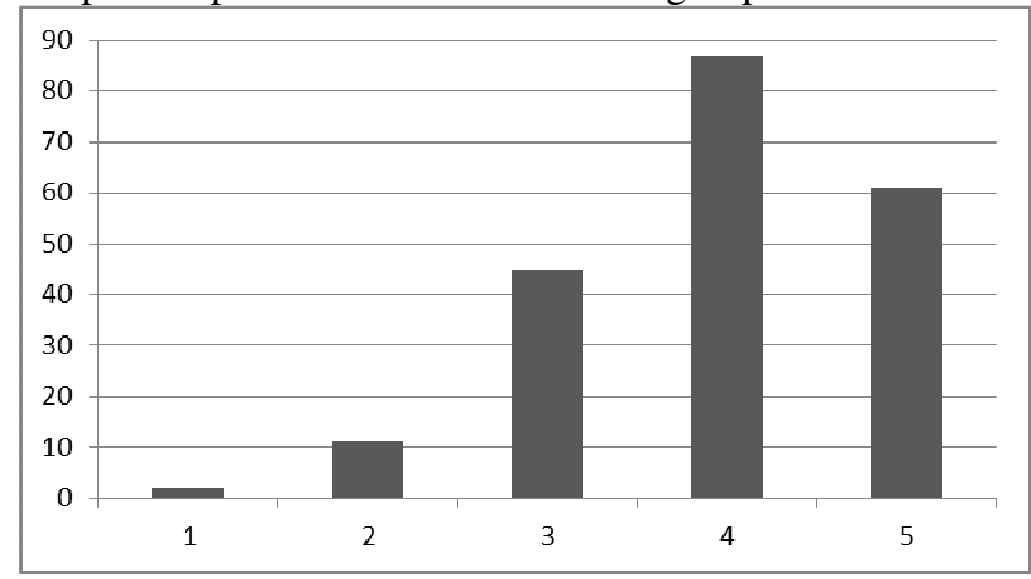

Source: Authors' own research

Table 1 Number of districts in the established groups - knowledge infrastructure

\begin{tabular}{|l|c|c|c|c|c|c|c|}
\hline Region & $\mathbf{1}$ & $\mathbf{2}$ & $\mathbf{3}$ & $\mathbf{4}$ & $\mathbf{5}$ & mean & total \\
\hline Prague & 1 & 0 & 0 & 0 & 0 & $\mathbf{1 . 0}$ & $\mathbf{1}$ \\
\hline Stř̌edočeský & 0 & 0 & 8 & 11 & 7 & $\mathbf{4 . 0}$ & $\mathbf{2 6}$ \\
\hline Jihočeský & 0 & 1 & 5 & 8 & 3 & $\mathbf{3 . 8}$ & $\mathbf{1 7}$ \\
\hline Plzeňský & 0 & 1 & 1 & 3 & 10 & $\mathbf{4 . 5}$ & $\mathbf{1 5}$ \\
\hline Karlovarský & 0 & 0 & 2 & 3 & 2 & $\mathbf{4 . 0}$ & $\mathbf{7}$ \\
\hline Ústecký & 0 & 1 & 5 & 8 & 2 & $\mathbf{3 . 7}$ & $\mathbf{1 6}$ \\
\hline Liberecký & 0 & 1 & 2 & 4 & 3 & $\mathbf{3 . 9}$ & $\mathbf{1 0}$ \\
\hline Královéhradecký & 0 & 1 & 3 & 7 & 4 & $\mathbf{3 . 9}$ & $\mathbf{1 5}$ \\
\hline Pardubický & 0 & 1 & 3 & 7 & 4 & $\mathbf{3 . 9}$ & $\mathbf{1 5}$ \\
\hline Vysočina & 0 & 1 & 2 & 7 & 5 & $\mathbf{4 . 1}$ & $\mathbf{1 5}$ \\
\hline Jihomoravský & 1 & 0 & 4 & 8 & 8 & $\mathbf{4 . 0}$ & $\mathbf{2 1}$ \\
\hline Olomoucký & 0 & 1 & 3 & 6 & 3 & $\mathbf{3 . 8}$ & $\mathbf{1 3}$ \\
\hline Zlínsḱ́ & 0 & 1 & 3 & 7 & 2 & $\mathbf{3 . 8}$ & $\mathbf{1 3}$ \\
\hline Moravskoslezský & 0 & 2 & 4 & 8 & 8 & $\mathbf{4 . 0}$ & $\mathbf{2 2}$ \\
\hline In total & $\mathbf{2}$ & $\mathbf{1 1}$ & $\mathbf{4 5}$ & $\mathbf{8 7}$ & $\mathbf{6 1}$ & $\mathbf{3 . 9}$ & $\mathbf{2 0 6}$ \\
\hline
\end{tabular}

Source: Authors' own research 
With two exceptions, there are no significant differences between the regions according to the mean of the position of the districts within the classification - the range of the corresponding mean values is from 3.7 in the Ústecký region to 4.1 in the Vysočina region. The exceptions are the Prague and the Plzeňský region with the mean value of 4.5. This fact is caused by the clear dominating character of Plzeň within the system of municipalities of the region.

\section{Conclusions}

Besides high quality of education including highly specialized knowledge (practically used within relevant labour markets, starting with local markets as regards apprenticeship education), the creation and the transfer of new knowledge generated by the development of science and research, which is then commercialized in the form of innovations, are considered the main positive effects of education infrastructure from the perspective of the business segment.

A logical precondition for education quality enhancement is its financial support especially from public means and an elaborated system of assessment of its system components of an appropriate infrastructure, starting with secondary vocational education up to universities and colleges (in 2007 the average annual non-investment subsidy per a student of PUC was $72.000 \mathrm{Czk}$ ). The current conditions can be considered unsatisfactory as tertiary education institutions live in uncertainty as regards the amount of their future incomes due to the fact that the state demands them to increase the numbers of students but is not willing to guarantee a corresponding rise in financial means. A solution is expected from the reform of tertiary education (Matějü, 2009) which is in progress and which attempts at a systematic solution of the management of UC (roles of individual bodies), the definition of UC typology (research universities or faculties and those that will solely concentrate on teaching), the issue of financing and also the related involvement of private means (especially the question of school fees, their possible forms and amounts); all this is in relation to the enhancement of the quality of the provided education and the efficiency of the invested public means.

In the area of science and research of the Czech Republic, the most unsatisfactory phenomenon is the cooperation between the public and the private sectors, which was one of the reasons why former departments of the Academy of Sciences of the Czech Republic gained their own legal person (thanks to the new legal form of PRI) and thus a higher flexibility when cooperating with external entities. Another support tool could be various subsidy programs financing projects of cooperation between both sectors. In the Czech Republic, there is currently the Operational Program (OP Enterprise and Innovations), from which e.g. clusters are supported. Also the technology transfer and the protection of intellectual property in the Czech Republic represent considerable drawbacks. The total expenditures on research and development in the Czech Republic in 2008 were $1.41 \%$ of the gross domestic product, whereas the EU27 average is $1.92 \%$ and the EU15 average is even $2.01 \%$. On the other hand, the Czech Republic has the highest R\&D expenditures out of the countries of the Visegrad Four (Hungary $1.00 \%$, Poland $0.60 \%$ and Slovakia $0.47 \%$ ). In the EU, the highest expenditures are achieved by Finland and Sweden (both $3.7 \%$ ). Over two thirds of the expenditures on R\&D in the Czech Republic go to the business sector, which is also the highest proportion within the V4 countries and which approximates the EU15 average (Eurostat I). It follows that the weak point is the expenditures on public research and development (the government, universities). From the perspective of NUTS2 regions, the highest expenditures in the Czech Republic are found in regions Střední Čechy $(2.36 \%)$, Praha $(2.3 \%)$ and Jihovýchod $(1.23 \%)$. The worst situation is in regions Severozápad $(0.28$ 
$\%)$, Moravskoslezsko (0.68 \%) and Střední Morava (0.85). The best European regions reach the proportion of expenditures on R\&D of over $6 \%$ of the GDP (Eurostat II). The expenditures on research and development can be (especially in the private sector) stimulated by means of various tax-related instruments, for example tax allowances, tax deductions, depreciations, special tax incentives or reliefs on health insurance and social security for research employees. A positive step is that since 2005 organizations have been able to deduct $100 \%$ of expenditures on their own research and development from the tax base. This practically means that the R\&D expenditures can be deducted twice.

Only about $2 \%$ of innovation enterprises in the Czech Republic apply for patents. Large innovation enterprises apply more often $(10.5 \%)$ than medium sized $(3.7 \%)$ and small $(1.2$ $\%$ ) enterprises (CZSO, 2010). The small activity of enterprises is also obvious considering the number of applications for the European patent (EPO patent). In 2008 there were 19.91 EPO patent applications in the Czech Republic per a million inhabitants. The situation in the surrounding countries is not better (Hungary 17.76; Slovakia 6.23; Poland 6.01). The most active countries regarding patents are Sweden (293.56), Germany (275.55), Finland (232.54) and Denmark (228.49). In some European regions (especially in Germany) the number of EPO patents per a million inhabitants ranges around 600 (Eurostat I). The support for patent activity is also a focus of some subsidy programs, specifically the Innovation Programme (OP Enterprise and Innovations). The instruments for the support for patenting can also work at regional level. STP and BI often provide more affordable consulting services in this area or more affordable services to patent representatives. Moreover, the first Patent and Licence Fund (South Moravian Innovation Centre) was established at regional level. The fund provides more affordable loans for patent-related activities.

The above mentioned issues are also in the focus of the National Research, Development and Innovation Policy. This has nine basic goals which concentrate e.g. on the management and efficiency of RDI, cooperation in RDI (public-private and international), human resources and stimulating environment. These goals also involve the increase in expenditures on $R \& D$, the support of intellectual property protection, the establishment of the Technological Agency of the Czech Republic, and the support for technology transfer (National RDI Policy of the CR).

\section{References:}

[1] CZSO (2010). Innovation activities of enterprises in the Czech Republic in 2006 - 2008. Prague: CZSO, 2010. ISBN 978-80-250-2024-1.

[2] CZSO. Městská a obecní statistika (MOS) - výběr z databáze.

[3] EUROSTAT (I). Available at: http://epp.eurostat.ec.europa.eu (23.9.2010)

[4] EUROSTAT (II). Regional statistics. Available at: http://epp.eurostat.ec.europa.eu/ portal/page/portal/region_cities/regional_statistics (23.9.2010)

[5] HAMPL, M. (2005). Geografická organizace společnosti v České republice: transformační procesy a jejich obecný kontext. Praha: DemoArt, 2005. ISBN 80-86746-02-X.

[6] IFO (1989). An empirical assessment of factors shaping regional competitiveness in problem regions in Europe. Munich 1989.

[7] INSTITUTE FOR INFORMATION ON EDUCATION (Yearbooks). Available at: http://www.uiv.cz/rubrika/97 (25.3.2009)

[8] KOČIŠOVÁ, K., TARTAL'OVÁ, A. (2010). Podnikaltel'ské prostredie a podnikatel'ský index malých a stredných podnikov na Slovensku. Acta academica karviniensia, Karviná: SU-OPF, 1/2010, s. 248-257. ISSN 1212-415X 
[9] KONEČNÝ, M., SKOKAN, K., ZAMARSKÝ, V. (2001). Inovační centra. Transferová inovační pracoviště. Inkubátory pro výchovu inovačních podnikatelů. Vědecko-technické parky v regionálním rozvoji. Ostrava: VŠB-TU, 2001. ISBN: 80-7078-873-9.

[10] MATĚJŮ, P. a kol. (2009) Bílá kniha terciárního vzdělávání. Praha: Ministerstvo školství, mládeže a tělovýchovy, 2009. Available at:

http://www.msmt.cz/uploads/bila_kniha/schvalena_bktv/BKTV_finalni_verze.pdf

[11] MINISTERSTVO ŠKOLSTVÍ, MLÁDEŽE A TĚLOVÝCHOVY. Rejstřík veřejných výzkumných institucí. Available at: http://rvvi.msmt.cz (31. 3. 2009).

[12] MINISTRY OF INDUSTRY AND TRADE. Operational Programme Enterprise and Innovations 2007 - 2013.

[13] National Research, Development and Innovation Policy of the Czech Republic in 2009-2015.

[14] NETHERLANDS ECONOMIC INSTITUTE in cooperation with ERNST \& YOUNG (1993). New location factors for mobile investment in Europe. Brussels - Luxembourg, Office for Official Publications of the European Communities, 1993.

[15] SCIENCE AND TECHNOLOGY PARKS ASSOCIATION OF THE CZECH REPUBLIC. Available at: http://www.svtp.cz (8.4.2009)

[16] TONEV, P. (2007) Institucionální báze výzkumu a vývoje a inovačně nosných obori̊ vysokého školství. In SLANÝ, A. a kol.: Faktory konkurenceschopnosti: (komparace zemí V-4). Brno: Masarykova univerzita, 2007. ISBN 978-80-210-4455-5.

[17] ÚSTAV PRO INFORMACE VE VZDĚLÁVÁNÍ. Databáze a zdroje. Available at: http://www.uiv.cz/rubrika/150 (10.4.2009)

[18] VITURKA, M. a kol (2010). Kvalita podnikatelského prostředí, regionální konkurenceschopnost a strategie regionálního rozvoje České republiky. Praha: Grada Publishing, 2010. ISBN 978-80-247-3638-9.

[19] VITURKA, M. a kol. (2003). Regionální vyhodnocení kvality podnikatelského prostředí $v$ České republice. Brno: Masarykova univerzita, 2003. ISBN 80-210-3304-5.

[20] VITURKA, M., ZÍTEK, V., KLÍMOVÁ, V., TONEV, P. (2010). Model for Evaluation of Business Environment Quality. Annals of Faculty Engineering Hunedoara - International Journal of Engineering, VIII, 2, pp. 159-164, 6 p. ISSN 1584-2665. 2010.

\section{JEL I23, R12}

\section{Ing. Vladimír Žítek, Ph.D.}

assistant professor

Department of Regional Economics and Administration

Faculty of Economics and Administration

Masaryk University

Lipová 41a, Brno, Czech Republic

zitek@econ.muni.cz

\section{Ing. Viktorie Klímová, Ph.D.}

assistant professor

Department of Regional Economics and

Administration, Masaryk University

Faculty of Economics and Administration

Lipová 41a, Brno, Czech Republic

klimova@econ.muni.cz 
doc. RNDr. Milan Viturka, CSc.

associate professor, head of department

Department of Regional Economics and Administration

Faculty of Economics and Administration

Masaryk University

Lipová 41a, Brno, Czech Republic

viturka@econ.muni.cz 